\title{
Utilization of Novel Technologies in Natural Product Research: Radical Progress
}

\section{Jagadevappa Patil}

VT's Shivajirao S Jondhle College of Pharmacy, Asangaon - 412 601, Thane, Maharashtra, India

*Corresponding author: Jagadevappa Patil, VT's Shivajirao S Jondhle College of Pharmacy, Asangaon-412 601, Thane, Maharashtra, India, Tel: 9448816812; E-mail: pharmajspatil@gmail.com

Received date: April 07, 2016; Accepted date: April 09, 2016; Published date: April 14, 2016

Copyright: (c) 2016 Patil J. This is an open-access article distributed under the terms of the Creative Commons Attribution License, which permits unrestricted use, distribution, and reproduction in any medium, provided the original author and source are credited.

\section{Introduction}

Present day health care scientists are engaged in development of herbal formulations for all kind of health related problems as an alternative to modern medicine which show high level of side effects. Now a day's use of indigenous medicines from plant origin has enormously increased worldwide. The world market for herbal drugs, herbal products and raw materials is estimated as US $\$ 80-90$ billion and is expected to grow [1] to US $\$ 5$ trillion by the year 2050. India is known for immense wealth of long established acquaintance and perception in the use of herbal medicines since ancient time. Indian herbal formulation industry is growing enormously every year with widespread market growth per annum. The increased global demand for herbal plants and their various constituents opened a new avenue to expand the Indian trade and commerce [2]. The scientific validation and technological standardization of herbal drugs may be achieved using a safe path of reverse pharmacology approach based on traditional knowledge database [3]. This may help in drug discovery, development and therapeutics, more than all, may help in dealing with a distinctive Western bias against Indian traditional medicine [4].

\section{Herbal Drug Technology}

Technology ply vital role in all most all the fields of our daily life. Pharmaceutical technology is utilized in the development of medicinal products. Similarly, herbal drug technology is utilized to transfer the plant materials into medicines, where it is very much essential to take care about proper integration of modern advanced scientific approaches and traditional wisdom in order to standardize and control the quality of final herbal product. Herbal health care products vary in composition and characteristics due to their variable sources and chemical complexity. Proper identification and quality assurance of the raw material is, therefore, an essential preliminary step to ensure reproducible quality herbal drugs, which contributes to its safety and efficacy $[5,6]$.

\section{Herbal Drug Technology and Molecular Markers}

Since, herbal products contains poly medicinal constituents make it impossible to analyse them all qualitatively or quantitatively. The analysis of constituents and estimation of various contaminants needs advanced analytical techniques. Some chemical and biological markers developed by these techniques are found to be useful in stability testing and biological standardization of these products. In order to ensure the quality, efficacy and safety of herbal products WHO has given guidelines for identification and evaluation of traditional medicines through the application of molecular markers [7]. In these modern days, pharmacognosy is being considered as a molecular science due to the ability of molecular markers as vital tools in mutiny of biochemical compounds and macromolecules such as proteins and deoxyribonucleic acids (DNA). Molecular markers such as genetic markers are able to recognize plant at genomic level and institute novel values in standardization and quality control of herbal products and hence, considered most suitable and ubiquitous to most of herbs. Molecular markers have highly polymorphic nature, show prevailing legacy, occur frequently in genome, unbiased to environmental conditions and easily available, highly reproducible and allow easy exchange of data between laboratories [8]. Genetic based molecular markers find wider applications not only in the fields of physiology, taxonomy, embryology, genetics and many more but also widely used for validation of plant species of medicinal significance. The conventional evaluation parameters of herbal products based on chromatographic and spectroscopic techniques suffer with certain limitations due to their variable resources and chemical complexity. In the modern era of herbal drug development and discovery, biotechnology based applications ply the crucial role, whereas, current practice of herbal drug research focus on perfect integration of chemo type-based techniques and genotype based molecular techniques so as to achieve optimal characterization of herbal materials. Generally, biochemical constituents such as primary and secondary metabolites and other macromolecules such as nucleic acids are referred as molecular markers. However, secondary metabolites as molecular markers have been extensively utilized in standardization and quality control of herbal products.

\section{Conclusion}

World's several research institutes are involved in extensive research work on genomic based molecular markers which are successfully being used in identification and analysis of herbal medicines. Several Indian agricultural universities and research institutes are exploring DNA-based techniques in genotyping of medicinal plants. Easy extraction of DNA from fresh as well as dried organic plant tissues ensures simple detection of sample under test. Several methods which are based on DNA markers are being used for plant species characterization and detection of adulteration have been published. These molecular marker techniques can be used in for cultivation of medicinal plants, identification, and detection of adulterants and to prevent its counterfeit commercialization in herbal formulations. Advanced biotechnological approaches such as gene manipulation, cloning, sequencing, gene expression can be used to enhance the yield of secondary metabolites. Hence, the availability of such advanced molecular approaches in fingertips role of herbal drug technology is expected to be more challenging in future days. 
Citation: Patil J (2016) Utilization of Novel Technologies in Natural Product Research: Radical Progress. J Pharmacovigil 4: e152. doi: 10.4172/2329-6887.1000e152

Page 2 of 2

\section{References}

1. Report of the Inter Regional Workshop on Intellectual Property Rights in the Context of Traditional Medicine (2000) Bankok, Thailand.

2. Singh J, Singh AK, Khanuja SPS (2003) Medicinal plants: India's opportunities. Pharma Bio World 1: 59-66.

3. Vaidya AD, Vaidya RA, Nagaral SI (2001) Ayurveda and a different kind of evidence: from Lord Macaulay to Lord Walton (1835 to 2001 AD). J Assoc Physicians India 49: 534-537.
4. Patwardhan B, Chopra A, Vaidya ADB (2003) Herbal remedies and the bias against Ayurveda. Current Science 84: 1165-1166.

5. Straus SE (2002) Herbal medicines--what's in the bottle? N Engl J Med 347: 1997-1998.

6. De Smet PA (2002) Herbal remedies. N Engl J Med 347: 2046-2056.

7. Indian Herbal Pharmacopoeia (2002) Indian Drug Manufacturer's Association, Mumbai.

8. Joshi SP, Prabhakar KR, Gupta VS (1999) Current Science 77: 234. 